\title{
Biochemical characterization of a Kunitz inhibitor from Inga edulis seeds with antifungal activity against Candida spp.
}

\author{
Heloisa Xavier Dib ${ }^{1}$ - Daniella Gorete Lourenço de Oliveira ${ }^{1}$. Caio Fernando Ramalho de Oliveira ${ }^{1}$. \\ Gabriel Bonan Taveira ${ }^{2}$ Erica de Oliveira Mello ${ }^{2} \cdot$ Newton Valério Verbisk $^{3} \cdot$ Marilene Rodrigues Chang $^{4}$. \\ Dario Corrêa Juniorr ${ }^{4}$ Valdirene Moreira Gomes ${ }^{2} \cdot$ Maria Lígia Rodrigues Macedo $^{1}$
}

Received: 12 March 2018 / Revised: 3 July 2018 / Accepted: 19 November 2018 / Published online: 27 November 2018

○) Springer-Verlag GmbH Germany, part of Springer Nature 2018

\begin{abstract}
We describe the characterization of IETI, the first trypsin inhibitor purified from Inga edulis, a tree widely distributed in Brazil. Two-step chromatography was used to purify IETI, a protein composed of a single peptide chain of 19,685.10 Da. Amino-terminal sequencing revealed that IETI shows homology with the Kunitz family, as substantiated by its physicalchemical features, such as its thermal (up to $70^{\circ} \mathrm{C}$ ) and wide-range $\mathrm{pH}$ stability (from 2 to 10 ), and the value of its dissociation constant $(6.2 \mathrm{nM})$. IETI contains a single reactive site for trypsin, maintained by a disulfide bridge; in the presence of DTT, its inhibitory activity was reduced in a time- and concentration-dependent manner. IETI presented activity against Candida ssp., including C. buinensis and C. tropicalis. IETI inhibitory activity triggered yeast membrane permeability, affecting cell viability, thus providing support for the use of IETI in further studies for the control of fungal infections.
\end{abstract}

Keywords Trypsin inhibitor $\cdot$ Membrane permeability $\cdot$ Candida tropicalis $\cdot$ Candida buinensis

\section{Introduction}

The first records of fossils indicate the establishment of early land plants almost 500 million years ago (Heckman et al. 2001). This period was probably followed by first interactions of plants with microbes and fungi. Although we can only speculate about subsequent events, the evolution of

Communicated by Yusuf Akhter.

Maria Lígia Rodrigues Macedo

ligiamacedo18@gmail.com

1 Laboratório de Purificação de Proteínas e suas Funções Biológicas, Faculdade de Ciências de Alimentos e Nutrição, Universidade Federal do Mato Grosso do Sul, Campo Grande, MS 79070-900, Brazil

2 Laboratório de Fisiologia e Bioquímica de Microrganismos, Universidade Estadual do Norte Fluminense, Campos dos Goytacazes, RJ 28013-600, Brazil

3 Embrapa Gado de Corte, Campo Grande, MS 79106-550, Brazil

4 Laboratório de Pesquisas Microbiológicas, Faculdade de Ciências de Alimentos e Nutrição, Universidade Federal do Mato Grosso do Sul, Campo Grande, MS 79070-900, Brazil plants has triggered molecular interactions with all other organisms (Chisholm et al. 2006); our current knowledge about plants shows that several defense-related genes have emerged to deal with threats to survival and plant perpetuation. These genes encode proteins that include the chitinases, glucanases, lipid transfer proteins, chitin-binding lectins, thionins and peptidase inhibitors (Melo et al. 2002), which present a myriad of biological activities that have been biochemically refined throughout the extensive and constant process of evolution.

Peptidase inhibitors (PIs) are a group of heterogeneous proteins, involved in plant defense against insects and pathogens, which exert their effects by the inhibition of peptidases. These proteins are widely distributed in plant tissues and play dual roles in both defense and storage. The biological properties of PIs can be mediated by molecular regions that differ from the protein's reactive site or via other mechanisms beyond the formation of the peptidase-inhibitor complex. The wide spectra of biological activities of the PIs appear to be the consequence of a structural fold that is shared by some PIs, named the $\beta$-trefoil fold (Azarkan et al. 2011).

The Kunitz family of PIs presents the $\beta$-trefoil fold and is currently grouped in the MEROPS database as Family I3 
(Rawlings et al. 2012). The major enzymes inhibited by this family are serine, cysteine and aspartic peptidases; to date, Kunitz PIs have not been reported to inhibit metallopeptidases (Oliva et al. 2010). Most Kunitz inhibitors present a molecular mass of 10-25 kDa; however, a growing number of Kunitz inhibitors that have been characterized do not present a unique pattern of disulfide bridge numbers and polypeptide chains. Although the significance of PIs in plant tissues is related to plant protection, some PIs have been evaluated for their potential to control bacteria, fungi, cancer, viruses, and other human pathogens (Bhattacharyya and Babu 2009; Bijina et al. 2011; Li et al. 2014).

Species from the Candida genus are frequently found in human opportunistic infections. In Brazil, Candida albicans and $C$. tropicalis are most prevalent in the hospital environment (Kobayashi et al. 2004), and episodes of Candida infections showing resistance against azole antifungals have been overwhelming (Whaley et al. 2016). Cases involving Candida are the 4th most common among nosocomial bloodstream infections, but present a mortality rate of close to $50 \%$. As such, patients that need venous catheter placement, parenteral nutrition, surgical procedures, hemodialysis, amongst other procedures require prolonged broad-spectrum antibiotic therapy and are susceptible to infection (Kumar et al. 2018). New alternatives to control this and other microorganism are urgently needed and the Kunitz PIs, therefore, represent a group of promising molecules.

Our group has focused on the study of plants distributed in Mato Grosso do Sul, a state with two important Brazilian biomes: the Cerrado and Pantanal. These biomes house a high number of endemic species, some of which have not yet been described or characterized. Worryingly, the growth of cities and crops over natural coverage puts the discovery of new species at risk and may even cause the extinction of many others. Thus, our goal is to characterize new bioactive plant-derived molecules and show the importance of conservation from both the ecological and biotechnological points of view. The Inga genus is common in this region, with some species known to be sources of molecules of biotechnological interest (Macedo et al. 2007; Ramos et al. 2012; da Silva Bezerra et al. 2016). For the first time, we purified a trypsin inhibitor from Inga edulis seeds, and described it physic-chemical features in this report. This inhibitor, designated IETI (I. edulis trypsin inhibitor), belongs to the Kunitz family and demonstrates efficacy in the control of the Candida species. Since alternatives to control microbial infections are needed, we present herein the purification and physical-chemical and biological characterization of IETI.

\section{Materials and methods}

\section{Materials}

Chromatographic and electrophoretic supports were from GE Healthcare. Trypsin and chymotrypsin from bovine pancreas, $N$-benzoyl-DL-Arg $p$-nitroanilide (BAPNA) and $N$-succinyl-Ala-Ala-Pro-Phe $p$-nitroanilide (SAAPFPNA) substrates, bovine serum albumin (BSA), dithiothreitol (DTT), and electrophoresis reagents were purchased from Sigma-Aldrich. All other buffers and reagents acquired were of analytical grade.

Candida albicans (CE022) and Candida tropicalis (CE017) yeasts were obtained from the Departamento de Biologia, Universidade Federal do Ceará, Fortaleza, Brazil. The Candida buinensis (3982) was obtained from the mycology collection of the Universidade Federal de Pernambuco, Recife, Pernambuco, Brazil. The yeasts were maintained on Sabouraud agar (1\% peptone, 2\% glucose and $1.7 \%$ agar-agar) at the Laboratório de Fisiologia e Bioquímica de Microrganismos, at the Centro de Biociência e Biotecnologia, UENF, Campos dos Goytacazes, Rio de Janeiro, Brazil. Two Cryptococcus ssp. were used in this study: Cryptococcus gattii and Cryptococcus neoformans. C. gattii (CFR 59) was obtained from the mycology collection of the Fundação Oswaldo Cruz (Fiocruz); C. neoformans was detected in blood culture using an automated Bact/Alert system and identified employing an automated Vitek 2 Compact system (bioMérieux, France). Both Cryptococcus ssp. were maintained at the Laboratório de Pesquisas Microbiológicas, UFMS, Campo Grande, Brazil. Seeds of I. edulis were collected locally (Campo Grande, MS).

\section{Purification of IETI}

Inga edulis seeds were ground and extracted $(1: 10, \mathrm{w} / \mathrm{v})$ with $100 \mathrm{mM}$ sodium phosphate buffer, $\mathrm{pH} 7.6$, for $3 \mathrm{~h}$ at $4{ }^{\circ} \mathrm{C}$ and then centrifuged at $7500 \times g$ for $30 \mathrm{~min}$ at the same temperature. The supernatant was dialyzed against water at $4{ }^{\circ} \mathrm{C}$, lyophilized and denominated as crude extract (CE). The inhibitory activity of CE against trypsin was assayed. For IETI purification, the CE $(60 \mathrm{mg})$ was dissolved in $2 \mathrm{~mL} 50 \mathrm{mM}$ potassium phosphate buffer, pH 7.0, and loaded onto a Sephadex G-100 column $(80 \times 3 \mathrm{~cm})$ equilibrated with the same buffer. Fractions of $3 \mathrm{~mL}$ were collected at a flow rate of $40 \mathrm{~mL} \mathrm{~h}^{-1}$. The fractions with inhibitory activity against trypsin were pooled, lyophilized and loaded onto a trypsin-Sepharose column $(4.6 \times 80 \mathrm{~mm})$. This chromatographic step was performed in $\ddot{A K T A}$ pure $25 \mathrm{~L}$, equilibrated with $50 \mathrm{mM}$ potassium 
phosphate buffer, pH 7.6. The sample was previously dissolved in buffer A $\left(5 \mathrm{mg} \mathrm{mL}^{-1}\right)$ and the peaks were automatically collected at a flow rate of $1.5 \mathrm{~mL} \mathrm{~min} \mathrm{~m}^{-1}$, $50 \mathrm{mM}$ using $\mathrm{HCl}$ for elution of bound peak. Absorbance was monitored at $280 \mathrm{~nm}$.

\section{Polyacrylamide gel electrophoresis}

SDS-PAGE (12\%) was performed according to Laemmli (1970), using low-range molecular weight standards. Proteins were detected by staining with $0.1 \%$ Coomassie brilliant blue R-250.

\section{Protein quantification}

Protein concentrations were determined by Coomassie blue staining using the Bradford method (1976), adapted to a microplate protocol, with serially diluted BSA as standard.

\section{Inhibitory activity assays}

For trypsin inhibitory activity $\left(0.125 \mathrm{mg} \mathrm{mL}^{-1}\right)$, the enzyme was incubated with different concentrations of EtTI in $50 \mathrm{mM}$ Tris- $\mathrm{HCl}$ buffer, $\mathrm{pH}$ 8.0. After a 10-min incubation at $30{ }^{\circ} \mathrm{C}, 200 \mu \mathrm{L}$ of $1 \mathrm{mM} \mathrm{BAPNA}$ was added (final assay volume of $270 \mu \mathrm{L}$ ) and substrate hydrolysis was monitored at $410 \mathrm{~nm}$ for $30 \mathrm{~min}$, using a microplate reader (Multis$\operatorname{kan}^{\mathrm{TM}} \mathrm{GO}$, Thermo Scientific), according to Oliveira et al. (Oliveira et al. 2012). For chymotrypsin inhibitory activity $\left(1 \mathrm{mg} \mathrm{mL}^{-1}\right)$, the enzyme was incubated with different concentrations of EtTI in $50 \mathrm{mM}$ Tris- $\mathrm{HCl}$ buffer, $\mathrm{pH}$ 8.0. After a 10-min incubation at $30^{\circ} \mathrm{C}, 20 \mu \mathrm{L}$ of $1 \mathrm{mM}$ SAAPFPNA was added (final assay volume of $120 \mu \mathrm{L}$ ) and substrate hydrolysis was monitored at $410 \mathrm{~nm}$ for $5 \mathrm{~min}$.

\section{Amino acid sequencing}

IETI amino-terminal sequencing was carried out by Edman degradation on Shimadzu PPSQ-31B/33B. The equipment was previously calibrated with PTH-amino acid mixture standard and IETI bound to a PVDF membrane for analysis. Phenylthiohydantoin-amino acids were detected after separation on an RP-HPLC C18 column $(4.6 \mathrm{~mm} \times 250 \mathrm{~mm})$, according to the manufacturer's instructions. The resulting sequence from amino-terminal sequencing was subjected to an NCBI protein BLAST search and the sequences that produced significant alignments used in multiple alignments using the T-COFFEE Multiple Sequence Alignment Server (Notredame et al. 2000).

\section{Kinetic parameters}

The kinetic parameters of $\mathrm{Km}$ and dissociation constant (Ki) were analyzed with the aid of SigmaPlot (Systat Software, Inc.). The data obtained from assays using different substrate (0.4-1 mM BAPNA) and inhibitor concentrations $(0-11.78 \mu \mathrm{M}$ IETI $)$ were analyzed using the tight-binding inhibition study. The stoichiometric ratio between IETI and trypsin was also determined. Increasing concentrations of IETI were incubated with a fixed concentration of trypsin. All experiments were performed in triplicate.

\section{Stability of IETI activity}

The stability of EITI to thermal variation was evaluated by incubating an aliquot of inhibitor $\left(0.5 \mathrm{mg} \mathrm{mL}^{-1}\right.$ in $50 \mathrm{mM}$ Tris- $\mathrm{HCl}, \mathrm{pH}$ 8.0) for $30 \mathrm{~min}$ at different temperatures $\left(30-100{ }^{\circ} \mathrm{C}\right.$ ) or $\mathrm{pH}$ (from 2 to 10 ), followed by an assay to estimate the inhibitory activity against trypsin. To evaluate EtTI stability, following the reduction of disulfide bridges, EtTI was incubated with DTT at final concentrations of 1, 10 and $100 \mathrm{mM}$ for $15,30,60$ and $120 \mathrm{~min}$ at $30^{\circ} \mathrm{C}$. The reaction was ended by adding iodoacetamide at twice the amount of each DTT concentration. The inhibitory activity against trypsin was then determined. Experiments were carried out in triplicate.

\section{Antifungal activity assays}

\section{Growth inhibition assay}

Inocula from $C$. albicans, $C$. buinensis and C. tropicalis were transferred to Petri dishes containing Sabouraud agar and allowed to grow at $30{ }^{\circ} \mathrm{C}$ for $24 \mathrm{~h}$ and subsequently quantified in a Neubauer chamber. Initially, the yeast cells $\left(1 \times 10^{4}\right.$ cells $\left.\mathrm{mL}^{-1}\right)$ were incubated in $200 \mu \mathrm{L}$ of Sabouraud broth containing 200,300 and $400 \mu \mathrm{g} \mathrm{mL}^{-1}$ IETI. The assay was performed in 96 -well microplates at $30^{\circ} \mathrm{C}$ for $24 \mathrm{~h}$. Optical readings at $620 \mathrm{~nm}$ were obtained every $6 \mathrm{~h}$ during a 24-h period. The optical readings for Cryptococcus were obtained every $6 \mathrm{~h}$ during a 72-h period. Control cells were grown in the absence of IETI. The entire procedure was performed according to Broekaert et al. (1990) with minor modifications. The experiments were carried out in triplicate.

\section{Plasma membrane permeabilization}

Candida albicans, $C$. buinensis and $C$. tropicalis yeast cells $\left(1 \times 10^{4}\right.$ cells $\left.\mathrm{mL}^{-1}\right)$ were incubated in Sabouraud broth containing $200 \mu \mathrm{g} \mathrm{mL}^{-1}$ IETI. This assay was performed as described in "Growth inhibition assay". Plasma membrane permeabilization was measured using the DNA intercalator, 
Sytox green dye, according to the methodology described by Thevissen et al. (Thevissen et al. 1999b). After $24 \mathrm{~h}$ of IETI incubation, $96 \mu \mathrm{L}$ aliquots of each yeast cell suspension were incubated with $0.2 \mu \mathrm{M}$ Sytox green in a $1.5-\mathrm{mL}$ microtube, for $30 \mathrm{~min}$ at $25{ }^{\circ} \mathrm{C}$ under constant agitation. Cells were observed under differential interference contrast (DIC), using a microscope (Axiovison 4, Zeiss) equipped with a fluorescent filter set for detection of the fluorescein (excitation wavelength, $450-490 \mathrm{~nm}$, emission wavelength $500 \mathrm{~nm})$.

\section{Statistical analysis}

The results are expressed as means $\pm \mathrm{SD}$, where appropriate. Data were examined using one-way analysis of variance (ANOVA), with post test Tukey when $P<0.05$.

\section{Results and discussion}

For purification of IETI, we used a two-step process: gel filtration followed by bioaffinity chromatography. Since the IETI CE was rich in pigments, we used a bioaffinity column as the last purification step to extend its half-life. The G-100 column separated the IETI CE into three peaks, where the first peak was rich in pigments while the second peak presented the major trypsin inhibitory activity (PII, Fig. 1a). Peak P II was then pooled, dialyzed and subjected to bioaffinity chromatography using $\mathrm{HCl}$ in the elution step to yield IETI as a single peak (Fig. 1b) in homogeneous form. This purified IETI was verified by SDS-PAGE and MALDI-TOF (Fig. 2) and presented an intact mass of 19,685.10 Da. The trypsin-Sepharose sample yield was $6.6 \%$, representing a purification of 12-fold (Table 1).

Amino terminal sequencing identified the first 24 amino acids of IETI as ( $\mathrm{NH}_{2}$-GVGLIGLGEMVKNGGKYYIVPAIN-COOH), demonstrating homology with the Kunitz inhibitor family, and presenting the highest similarity with inhibitors from Cicer arietinum (90\%) (Srinivasan et al. 2005), Medicago truncatula (90\%) (Tang et al. 2014), Adenanthera pavonina (90\%) (Richardson et al. 1986), Canavalia lineata (75\%) (Terada et al. 1994), Inga vera (73\%) (da Silva Bezerra et al. 2016), Inga laurina (73\%) (Macedo et al. 2007), and Bauhinia variegata (69\%) (Di Ciero et al. 1998) (Fig. 3). With regard to its inhibitory activity, IETI inhibited only trypsin, similar to other trypsin inhibitors (ILTI and IVTI) from the Inga genus (Macedo et al. 2007; da Silva Bezerra et al. 2016). The specificity of molecules purified from the Inga genus for trypsin inhibition appears to be an important characteristic of these proteins, as the inhibitory activity of Kunitz
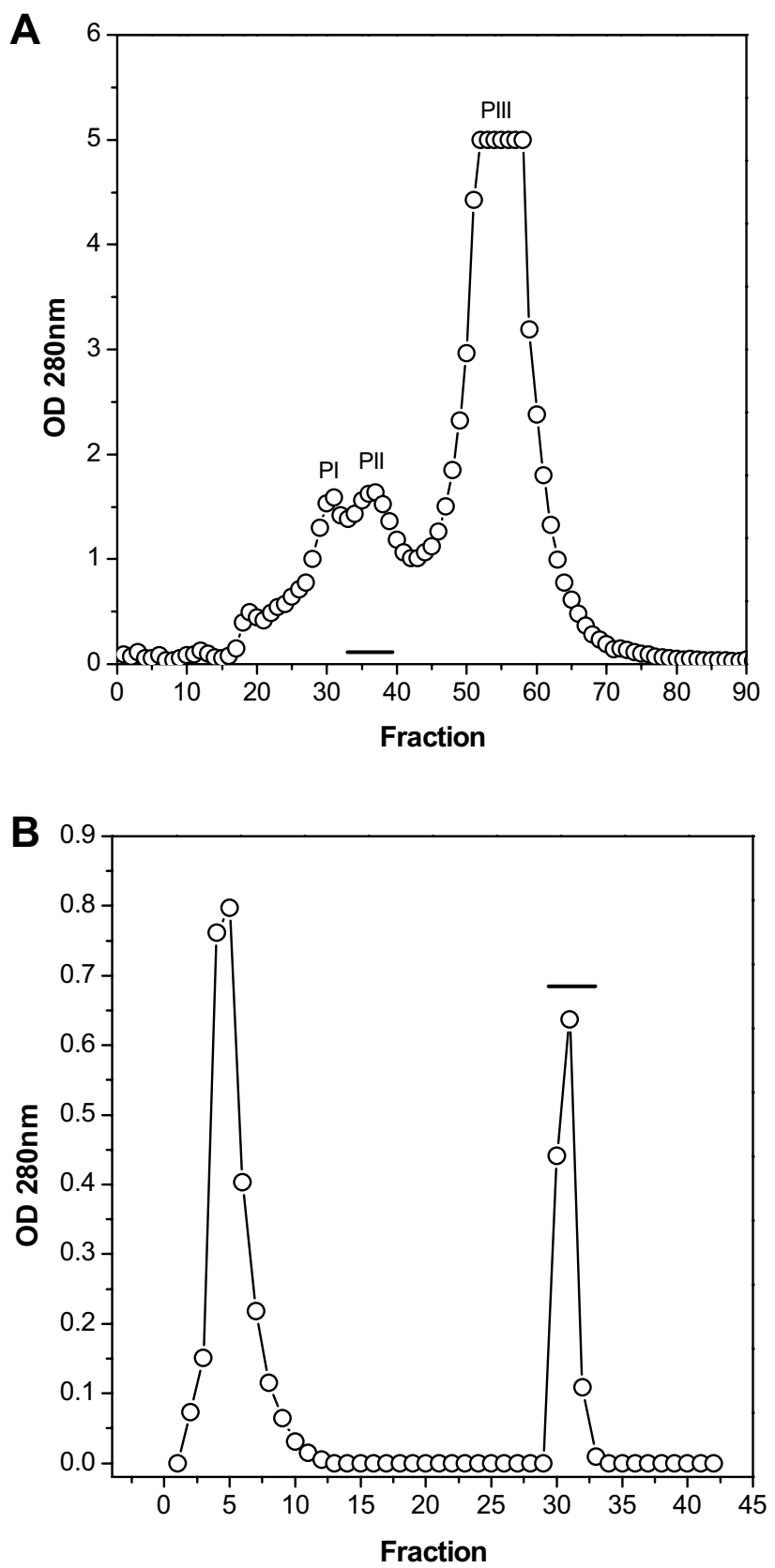

Fig. 1 IETI purification steps. a Sephadex G-100 and b trypsinSepharose chromatography. The fractions with inhibitory activity are shown with a dash

inhibitors varies widely. Inhibitors active against trypsin, chymotrypsin, elastase and other peptidase families, such as the cysteine peptidases, have been previously reported (Sumikawa et al. 2006; Migliolo et al. 2010; Oliva et al. 2010).

The inhibition stoichiometry of IETI was investigated to determine the number of reactive sites for trypsin. 
Fig. 2 MALDI-TOF analysis of IETI, showing the intact mass of the inhibitor. Inset: $12 \%$ SDS-PAGE showing the sample yielded from trypsin-Sepharose chromatography
Table 1 Purification steps of the I. edulis trypsin inhibitor

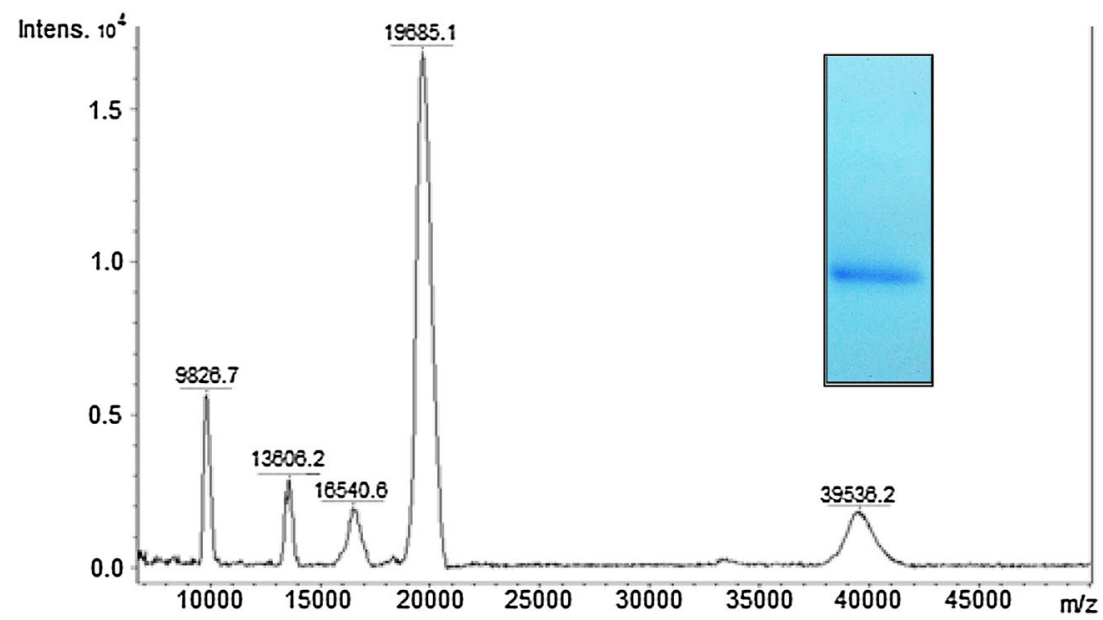

\begin{tabular}{lcllll}
\hline Step & $\begin{array}{l}\text { Total protein } \\
(\mathrm{mg})\end{array}$ & $\begin{array}{l}\text { Total activity } \\
\times 10^{6} \text { (units) }\end{array}$ & $\begin{array}{l}\text { Specific activity } \\
\times 10^{3} \text { (units/mg) }\end{array}$ & $\begin{array}{l}\text { Purification } \\
(\text { fold })\end{array}$ & Yield (\%) \\
\hline Crude extract & 2000 & 12.01 & 6.06 & 1 & 100 \\
G-100 & 660 & 2.19 & 33.18 & 5.47 & 18.23 \\
Trypsin-Sepharose & 110 & 0.8 & 72.72 & 12 & 6.66 \\
\hline
\end{tabular}

One trypsin inhibitory activity unit (TIU) was defined as the decrease in 0.01 units of absorbance per 30 min at $30^{\circ} \mathrm{C}$

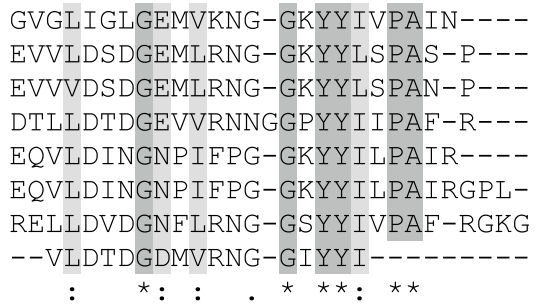

Fig. 3 Amino-terminal sequence alignment of IETI with other homologous Kunitz trypsin inhibitors. IVTI Inga vera, ILTI Inga laurina, BvTI Bauhinia variegata, CATI Cicer arietinum, MTTI Medicago truncatula, ApTI Adenanthera pavonina, CLTI Canavalia lineata. Asterisks indicate positions with fully conserved residues (dark gray boxes), colon indicates conservation between groups with similar properties (light gray boxes) and dot indicates conservation between groups of weakly similar properties

Increasing the molar inhibitor:enzyme ratio produced a linear pattern of inhibition with a molar ratio of $1: 1$ (Fig. 4). The initial high affinity observed between IETI and trypsin was similar to that observed for the trypsin inhibitor from Entada scandens (Lingaraju and Gowda 2008) and followed the pattern observed for PIs with single reactive sites. The experimentally determined dissociation constant (Ki) was $6.2 \mathrm{nM}$, and the enzyme showed

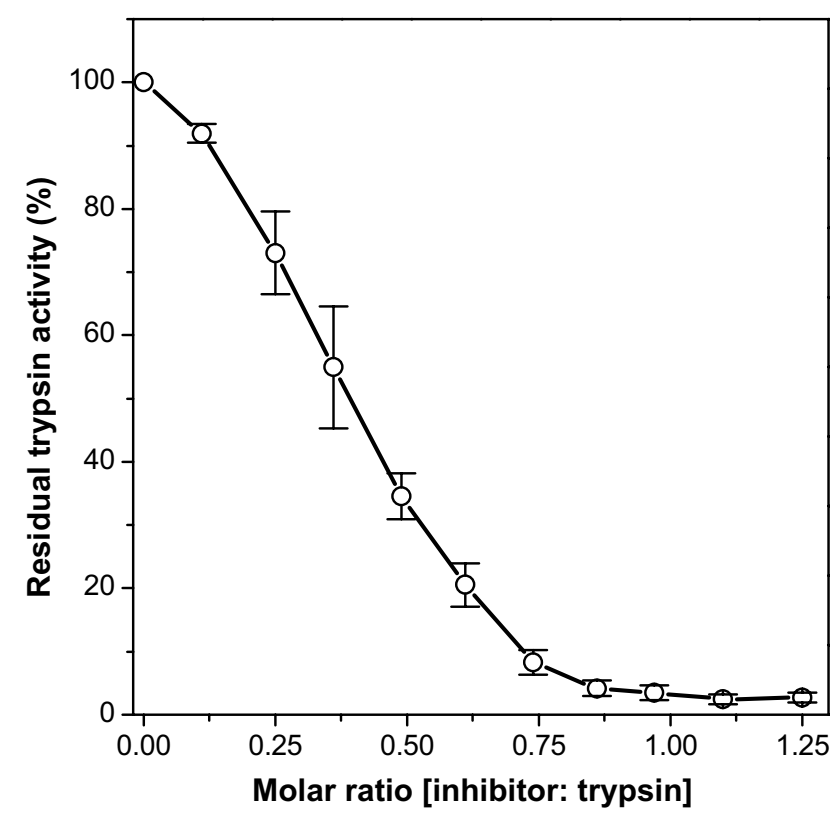

Fig. 4 Inhibition stoichiometry of IETI and bovine trypsin. Increasing concentrations of IETI were added to a fixed concentration of enzyme and the residual enzymatic activity determined 
Fig. 5 Stability of IETI over a range of $\mathbf{a} \mathrm{pHs}$ and $\mathbf{b}$ temperatures. $\mathbf{c}$ Effect of DTT on the inhibitory activity of IETI

high affinity to bovine trypsin, as also reported for other Kunitz inhibitors (Macedo et al. 2007; Oliveira et al. 2012; Ramalho et al. 2018).

The stability of IETI inhibitory activity was assayed over a range of temperatures, $\mathrm{pHs}$ and in the presence of the reducing agent, DTT. The inhibitor exhibited remarkable stability over a pH range (Fig. 5a) of 2-10. Although these $\mathrm{pH}$ values did not affect the protein's inhibitory activity, temperature and DTT affected IETI activity. Temperatures of up to $70{ }^{\circ} \mathrm{C}$ did not alter the inhibitory activity of IETI (Fig. 5b); however, a loss of inhibitory activity of approximately $50 \%$ was observed at $80^{\circ} \mathrm{C}$, while temperatures of $90^{\circ} \mathrm{C}$ and $100{ }^{\circ} \mathrm{C}$ reduced the activity of IETI by $60 \%$ and $68 \%$, respectively. Even the lowest DTT concentration assayed $(1 \mathrm{mM})$ was enough to affect the inhibitory activity (Fig. $5 \mathrm{c}$ ). The decrease in inhibitory activity ranged from 40 to $70 \%$ within 60 min of incubation. Exposure to DTT for longer periods $(120 \mathrm{~min})$ increased the loss in inhibitory activity, and this effect was both dose and time dependent. DTT probably decreased the activity of IETI by reducing the enzyme's disulfide bridges, as the effect of DTT on inhibitory activity depends upon its topological localization in relation to the protein's reactive site. When disulfide bridges are involved in reactive site structural maintenance, minimal concentrations of DTT have significant effects upon an enzyme's inhibitory activity. However, some PIs possess a reactive site that is stabilized by hydrogen bonds; for these proteins, DTT has no effect on inhibitory activity even at high concentrations. This characteristic has been previously reported for ETI, a trypsin inhibitor from Erythrina caffra (Onesti et al. 1991). For EATI, a trypsin inhibitor from E. acaciifolia (Oliveira et al. 2012), a disulfide bridge was found to be involved in the maintenance of overall structure, and the reduction of this disulfide bridge led to the reduced stability of the enzyme against thermal and $\mathrm{pH}$ variation. With regard to IETI, there is a clear involvement of the disulfide bridge in reactive site stabilization; this feature could be explored during miniaturization of the molecule and it may be possible to synthesize small reactive sites or even cyclic peptides for further experiments.

The potential of IETI to control Candida ssp. was evaluated to determine whether this protein has antifungal activities. The effect of IETI on fungal growth was evaluated for three species; Fig. 6 demonstrates that IETI affected each species differently. While no inhibition of $C$. albicans was observed (Fig. 6a), IETI inhibited the growth of $C$. tropicalis by approximately $50 \%$ at all concentrations tested (Fig. 6b).
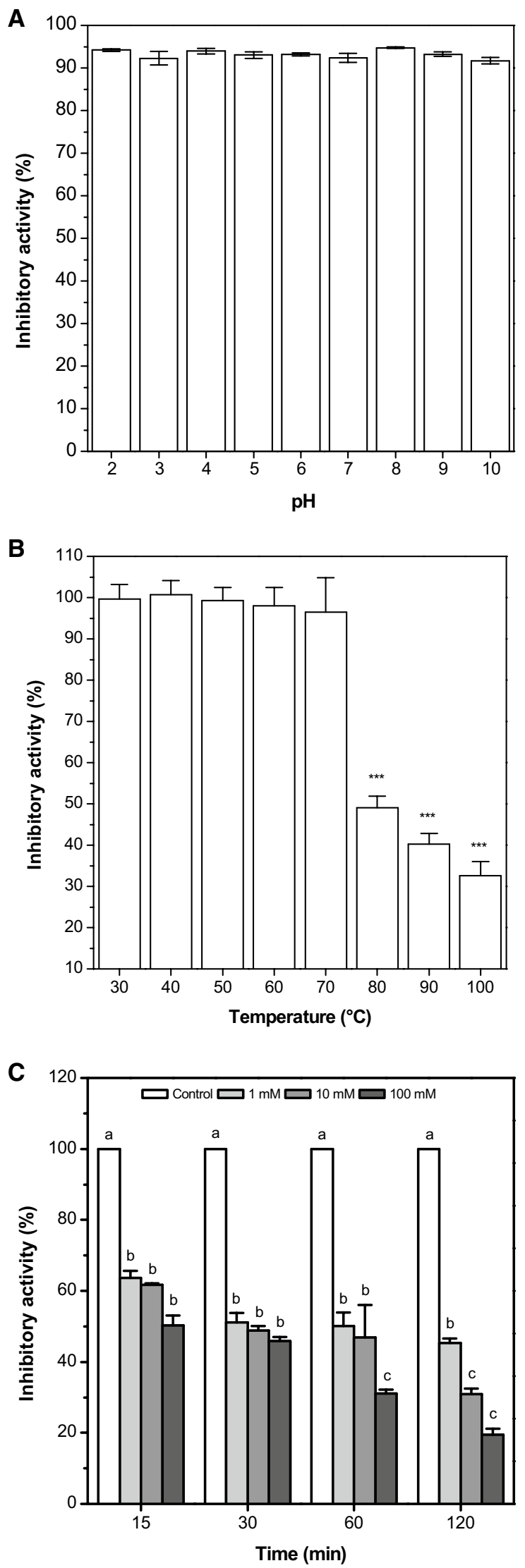
Fig. 6 Assay of the growth inhibitory effects of IETI on Candida strains: a C. albicans, b C. tropicalis, and c C. buinensis, treated with different concentrations of inhibitor $\left(200,300\right.$ and $\left.400 \mu \mathrm{g} \mathrm{mL}^{-1}\right)$ for $24 \mathrm{~h}$. Optical readings were measured at $620 \mathrm{~nm}$ and results represent the mean \pm standard deviation of triplicate values

Of the three species, $C$. buinensis was the most sensitive to IETI, demonstrating inhibitions of $51 \%, 81 \%$ and $87 \%$ for 200, 300 and $400 \mu \mathrm{g} \mathrm{mL}^{-1}$ IETI, respectively (Fig. 6c). The $\mathrm{IC}_{50}$ of IETI for $C$. tropicalis and $C$. buinensis was found to be $200 \mu \mathrm{g} \mathrm{mL}^{-1}$. From the molecular mass of IETI, an $\mathrm{IC}_{50}$ of $10.2 \mu \mathrm{M}$ was calculated, which is a similar $\mathrm{IC}_{50}$ to those reported for other plant molecules (Kim et al. 2005; Zottich et al. 2013; Taveira et al. 2016). Since different proportions of inhibition were observed, we investigated whether IETI alters the membrane integrities of $C$. tropicalis and $C$. buinensis by fluorescence microscopy.

IETI-treated $C$. buinensis cells presented prominent labeling for the Sytox probe (Fig. 7), indicating that the inhibitor was able to affect the structural integrity of the plasma membrane, allowing the entry and labeling of the dye. In control cells, we noticed a normal morphology and distribution, with rounded and well-defined cells, and low detection of fluorescence. At its $\mathrm{IC}_{50}$, IETI treatment $\left(200 \mu \mathrm{g} \mathrm{mL}^{-1}\right)$ caused severe changes in both the morphology and distribution of $C$. buinensis, with loss of rounded shape and the visualization of cytoplasmic disorganization, in addition to an observed difficulty for the cells to release buds (Fig. 7, inset). A similar membrane permeabilization was also observed when $C$. tropicalis was incubated with IETI, as demonstrated by the higher number of probe-tagged cells when compared to control cells (Fig. 8). Such alterations are commonly observed in intoxicated cells in response to fungicidal compounds. In contrast, the effects of IETI on cytoplasmic disorganization and bud release impairment in C.tropicalis were less evident. Finally, IETI-treated $C$. albicans did not present fluorescence labeling (data not shown). These differences in fungal susceptibility might suggest that the antifungal activity of IETI is initially mediated by specific interactions on the membrane surface.

The assays carried out with Cryptococcus ssp. showed the IETI was not able to control the growth of the yeast (Fig. 9). The Cryptococcus genus is composed by oval and round yeasts (4-6 $\mu \mathrm{m}$ in diameter), surrounded by a capsule that can be up to $30 \mu \mathrm{m}$ thick (Page et al. 2008). The capsule is majorly composed by glucuronoxylomannan and galactoxylomannan, with a minor proportion of mannoproteins (Zaragoza et al. 2009). The lack of activity of IETI on Cryptococcus ssp. might be related to the ability of the inhibitor to cross the polysaccharide capsule and to reach the plasma
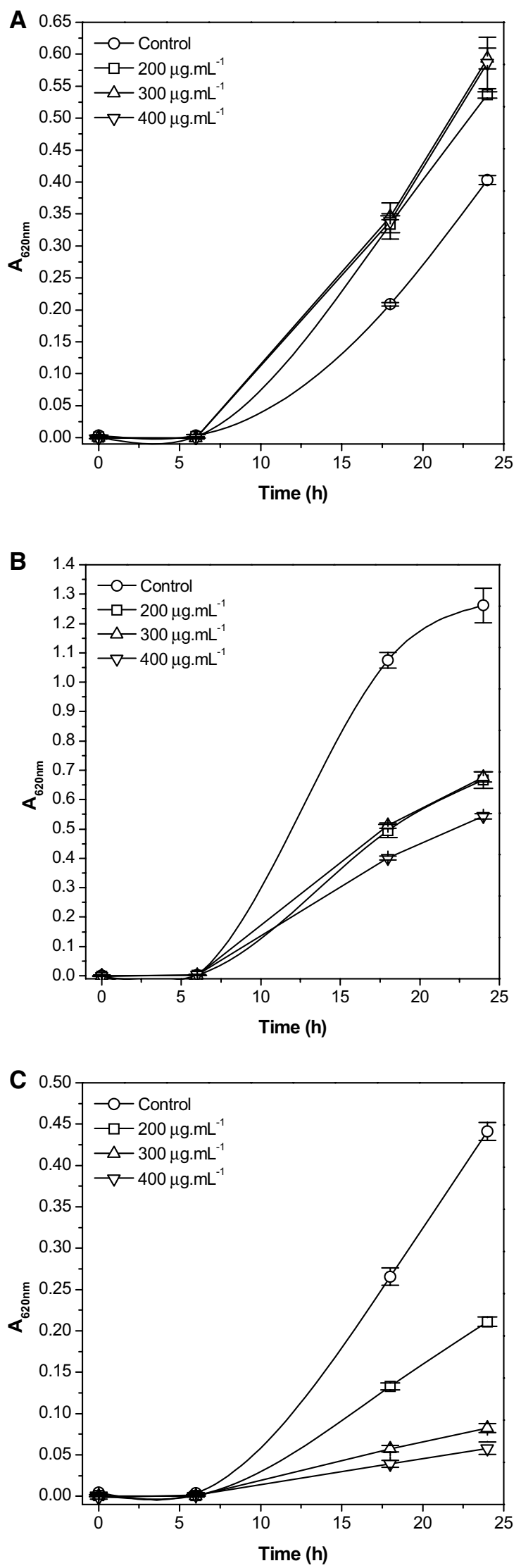
Fig. 7 DIC and fluorescence microscopy showing the effect of $200 \mu \mathrm{g} \mathrm{mL}^{-1}$ IETI on $C$. buinensis using a membrane permeabilization assay. Bars $20 \mu \mathrm{m}$. The asterisk in the right image represents an enlarged image obtained from the left one

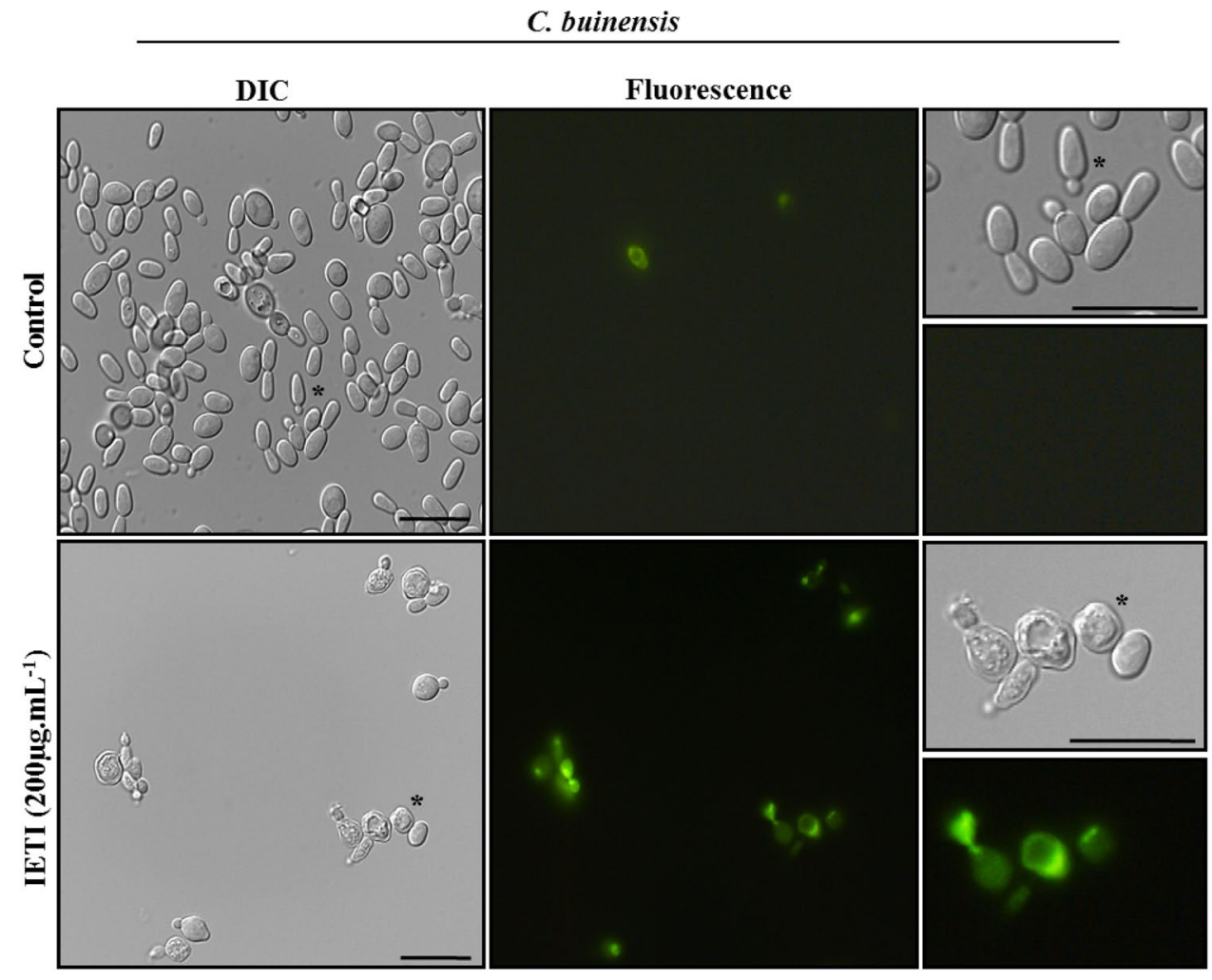

membrane surface. Thus, we suggest that IETI antifungal activity is triggered intracellularly, without directly affecting the plasma membrane, thus corroborating the results obtained with different Candida spp.

The use of natural compounds to treat microorganisms that are pathogenic to humans is increasing, partly motivated by episodes of overwhelming microbial resistance against commercial drugs (Sanglard et al. 1995; Sanglard and Odds 2002). Some plant molecules, such as defensins, PIs and antimicrobial peptides (AMPs) possess antifungal activities, as have been previously reported. The mechanism of action of these molecules is often mediated by the generation of reactive oxygen species (ROS). ROS cause oxidative stress and damage, and can lead to cell death. Several defensins interact with intracellular targets, leading to the overproduction of ROS (Vriens et al. 2014; Thery and Arendt 2018) and linear AMPs (Huang et al. 2010). An evaluation of the antifungal activity of the synthetic cowpea defensin, Cpthionin II (Thery and Arendt 2018), showed that this enzyme displays variable inhibition of fungal growth for different species (Fusarium culmorum, Aspergillus niger and Penicillium expansum), but that these effects are not sufficient to cause cell death. The antifungal activities of defensins may be modified by the presence of divalent cations (Vriens et al. 2014); moreover, the antifungal activities of some AMPs are also affected by the presence of cations (Bahar and Ren 2013; Kraszewska et al. 2016). Cations appear to affect the activities of these proteins by weakening the electrostatic interactions between these cationic molecules and the negatively charged membrane of microbial cells (Wu et al. 2003). Other effects include structural changes in the AMPs (Oard and Karki 2006), or stabilization of the microbial membrane by cations (Thevissen et al. 1999a; Thery and Arendt 2018). Another major concern for the application of AMPs is their sensitivity to proteolytic digestion by fungal peptidases. All these issues might compromise the commercial application of AMPs and defensins against fungal infections.

As such, PIs might present useful alternatives to bypass issues with digestion, sensibility to the presence of cations and electrostatic interactions reported for alternative molecules. PIs could trigger apoptosis in yeasts, blocking some important serine peptidases, such as metacaspases (Madeo et al. 1999) and nuclear mediator of apoptosis (Nma111p) (Carmona-Gutierrez et al. 2010). Metacaspases 
Fig. 8 DIC and fluorescence microscopy showing the effect of $200 \mu \mathrm{g} \mathrm{mL}^{-1}$ IETI on $C$. tropicalis using a membrane permeabilization assay. Bars $20 \mu \mathrm{m}$

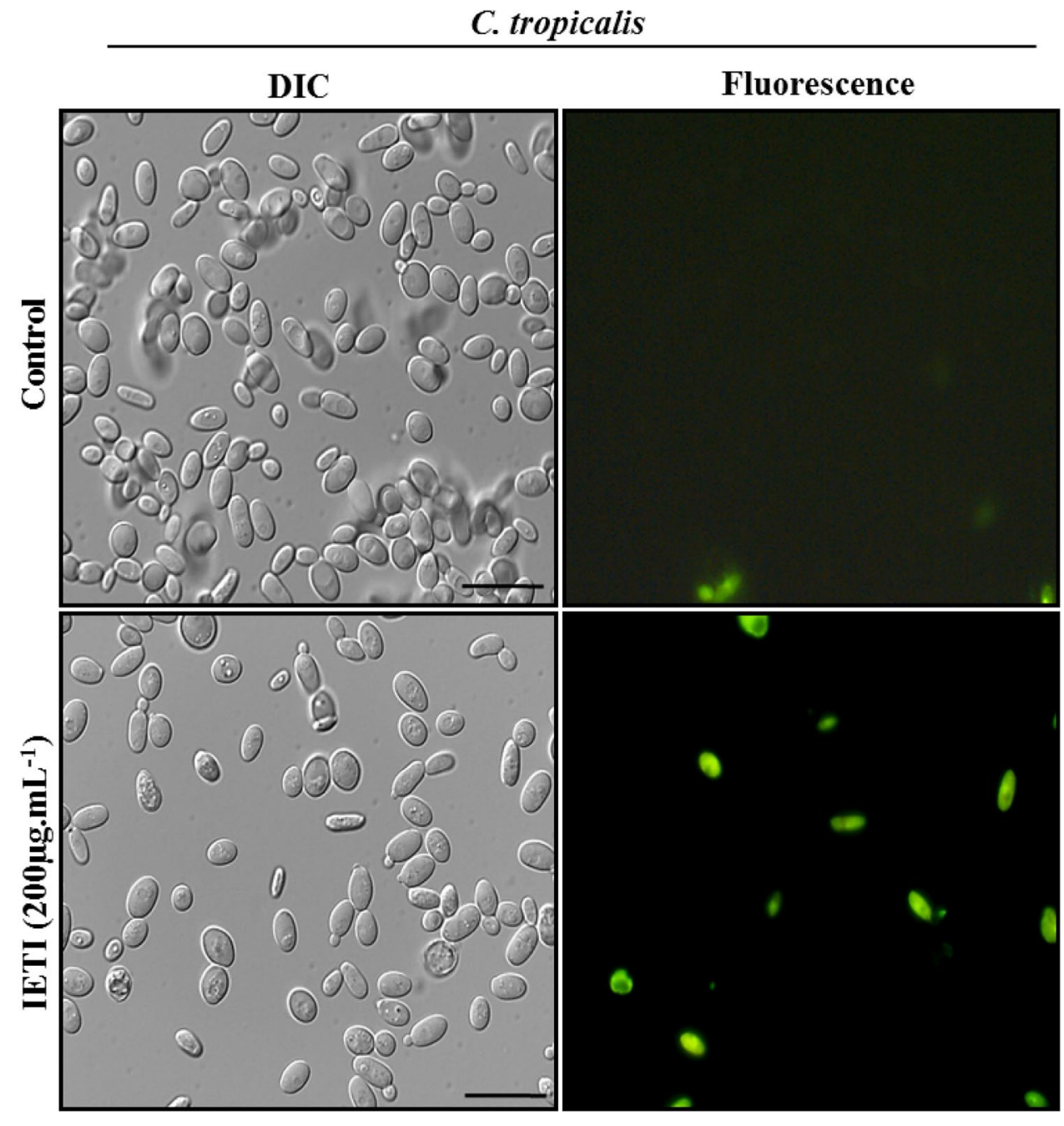

are orthologues of mammalian caspases with specificity for cleavage of the basic amino acids, Arg and Lys. These residues are commonly found in reactive sites in Kunitz inhibitors. Alternatively, the inhibition of nuclear mediators of apoptosis, serine peptidases also involved in yeast apoptosis, might be involved in the mechanism of action of PIs. Therefore, the use of PIs instead of defensins and AMPs may be preferred due to their specific and high-affinity interaction with vital peptidases, rather than depending upon cation concentration and the absence of proteolytic enzymes. Since part of the pathogenic mechanism of fungal infection involves the secretion of peptidases (Abad-Zapatero et al. 1996), the application of PIs to control fungal infections is pertinent. Molecules based on PIs could initially be designed and used to control topical infections. The experiments performed herein were performed for a few genera of microorganisms; we are carrying out further experiments with different species and models, as should also be done for other PIs.

In summary, we have purified and characterized a trypsin inhibitor from I. edulis, which to our knowledge is the third PI to be purified from Inga genus. IETI is a singleheaded Kunitz inhibitor that shares common features with the Kunitz family, such as thermal and pH stability. The reactive site of IETI is maintained in its native conformation due to the presence of a disulfide bridge; the reduction of this disulfide bridge with DTT abolishes the inhibitory activity of IETI. The antifungal activity of IETI is mediated 

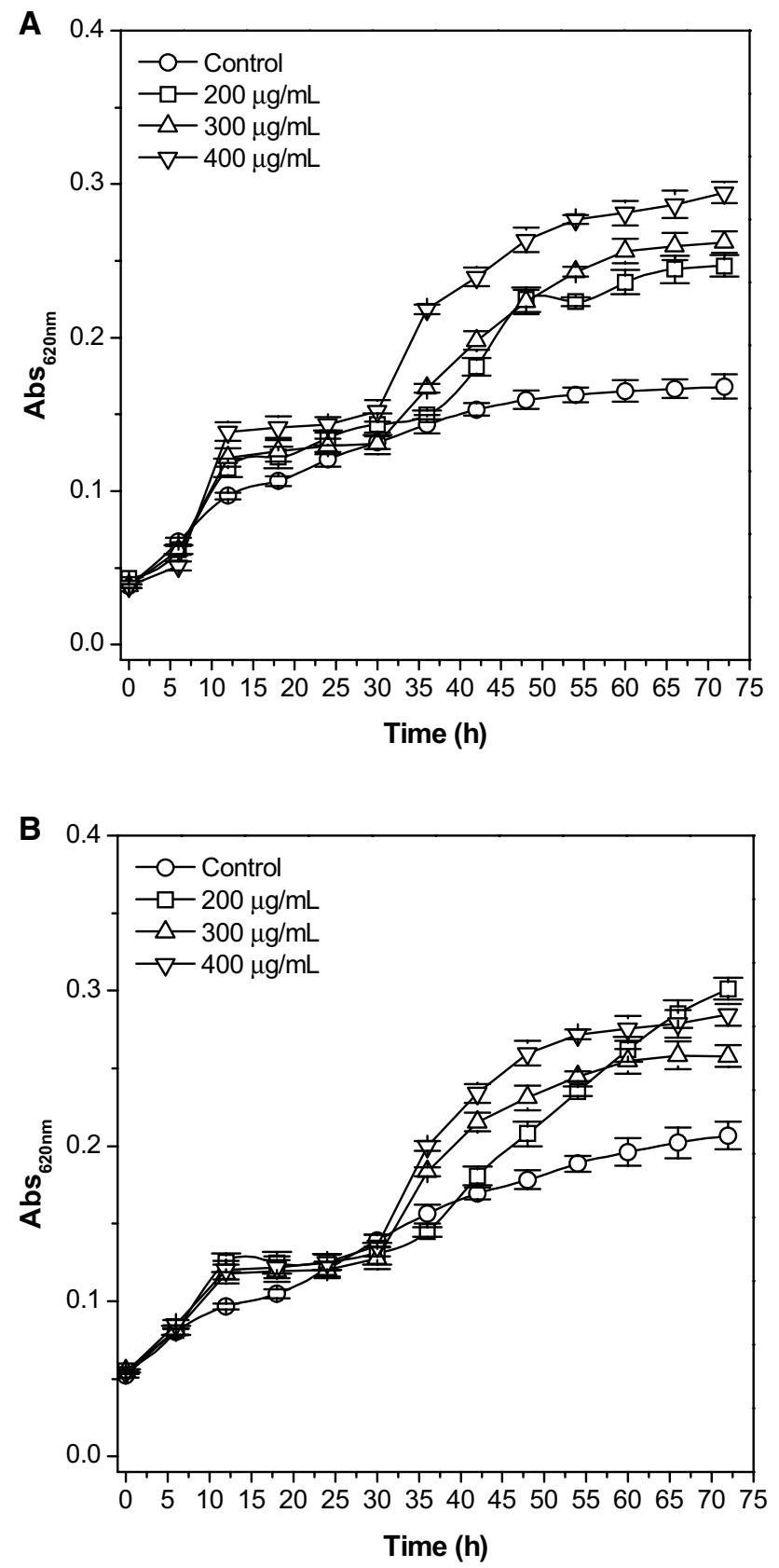

Fig. 9 Assay of the growth inhibitory effects of IETI on Cryptococcus strains: a $C$. gattii and b $C$. neoformans, treated with different concentrations of inhibitor (200, 300 and $400 \mu \mathrm{g} \mathrm{mL} \mathrm{mL}^{-1}$ ) for $24 \mathrm{~h}$. Optical readings were measured at $620 \mathrm{~nm}$ and results represent the mean \pm standard deviation of triplicate values

by its alteration of the plasma membrane, diverting energetic metabolism from physiological function to repair and inducing morphological alterations that affect cell viability or even trigger apoptosis by complexing with vital enzymes in this pathway. The potential use of PIs as antifungal compounds should be encouraged.
Funding This work was supported by CNPq (407127/2013-5), CAPES and FINEP.

\section{References}

Abad-Zapatero C et al (1996) Structure of a secreted aspartic protease from $C$. albicans complexed with a potent inhibitor: implications for the design of antifungal agents. Protein Sci 5:640-652

Azarkan M, Martinez-Rodriguez S, Buts L, Baeyens-Volant D, Garcia-Pino A (2011) The plasticity of the $\beta$-trefoil fold constitutes an evolutionary platform for protease inhibition. J Biol Chem 286:43726-43734

Bahar AA, Ren D (2013) Antimicrobial peptides. Pharmaceuticals 6:1543-1575

Bhattacharyya A, Babu CR (2009) Purification and biochemical characterization of a serine proteinase inhibitor from Derris trifoliata Lour. seeds: insight into structural and antimalarial features. Phytochemistry 70:703-712. https://doi.org/10.1016/j.phyto chem.2009.04.001

Bijina B et al (2011) Protease inhibitor from Moringa oleifera with potential for use as therapeutic drug and as seafood preservative. Saudi J Biol Scie 18:273-281. https://doi.org/10.1016/j. sjbs.2011.04.002

Bradford M (1976) A rapid and sensitive method for the quantitation of microgram quantities of protein utilizing the principle of protein-dye binding. Anal Biochem 72:248-254. https://doi. org/10.1016/0003-2697(76)90527-3

Broekaert WF, Terras FR, Cammue BP, Vanderleyden J (1990) An automated quantitative assay for fungal growth inhibition. FEMS Microbiol Lett 69:55-59

Carmona-Gutierrez D, Eisenberg T, Büttner S, Meisinger C, Kroemer G, Madeo F (2010) Apoptosis in yeast: triggers, pathways, subroutines. Cell Death Differ 17:763-773

Chisholm ST, Coaker G, Day B, Staskawicz BJ (2006) Hostmicrobe interactions: shaping the evolution of the plant immune response. Cell 124:803-814. https://doi.org/10.1016/j. cell.2006.02.008

da Silva Bezerra C et al (2016) Exploiting the biological roles of the trypsin inhibitor from Inga vera seeds: a multifunctional Kunitz inhibitor. Process Biochem 51:792-803

Di Ciero L et al (1998) The complete amino acid sequence of a trypsin inhibitor from Bauhinia variegata var. candida seeds. J Protein Chem 17:827-834

Heckman DS, Geiser DM, Eidell BR, Stauffer RL, Kardos NL, Hedges SB (2001) Molecular evidence for the early colonization of land by fungi and plants. Science 293:1129-1133

Huang Y, Huang J, Chen Y (2010) Alpha-helical cationic antimicrobial peptides: relationships of structure and function. Protein Cell 1:143-152

Kim J-Y, Park S-C, Kim M-H, Lim H-T, Park Y, Hahm K-S (2005) Antimicrobial activity studies on a trypsin-chymotrypsin protease inhibitor obtained from potato. Biochem Biophys Res Commun 330:921-927. https://doi.org/10.1016/j. bbrc.2005.03.057

Kobayashi CCBA, Fernandes OdFL, Miranda KC, de Sousa ED, Silva MdRR (2004) Candiduria in hospital patients: a study prospective. Mycopathologia 158:49-52

Kraszewska J, Beckett MC, James TC, Bond U (2016) Comparative analysis of the antimicrobial activities of plant defensin-like and ultrashort peptides against food-spoiling bacteria. Appl Environ Microbiol 82:4288-4298

Kumar A, Zarychanski R, Pisipati A, Kumar A, Kethireddy S, Bow EJ (2018) Fungicidal versus fungistatic therapy of invasive 
Candida infection in non-neutropenic adults: a meta-analysis. Mycology. https://doi.org/10.1080/21501203.2017.1421592

Laemmli U (1970) Cleavage of structural proteins during the assembly of the head of bacteriophage T4. Nature 227:680-685

$\mathrm{Li} \mathrm{Z} \mathrm{et} \mathrm{al} \mathrm{(2014)} \mathrm{Reconstructed} \mathrm{mung} \mathrm{bean} \mathrm{trypsin} \mathrm{inhibitor} \mathrm{targeting}$ cell surface GRP78 induces apoptosis and inhibits tumor growth in colorectal cancer. Int J Biochem Cell Biol 47:68-75. https:// doi.org/10.1016/j.biocel.2013.11.022

Lingaraju MH, Gowda LR (2008) A Kunitz trypsin inhibitor of Entada scandens seeds: another member with single disulfide bridge. Biochim Biophys Acta (BBA) Proteins Proteom 1784:850-855. https://doi.org/10.1016/j.bbapap.2008.02.013

Macedo MLR, Garcia VA, Freire MGM, Richardson M (2007) Characterization of a Kunitz trypsin inhibitor with a single disulfide bridge from seeds of Inga laurina (SW.) Willd. Phytochemistry 68:1104-1111. https://doi.org/10.1016/j.phyto chem.2007.01.024

Madeo F et al (1999) Oxygen stress: a regulator of apoptosis in yeast. J Cell Biol 145:757-767

Melo FR et al (2002) Inhibition of trypsin by cowpea thionin: characterization, molecular modeling, and docking. Proteins Struct Funct Bioinform 48:311-319

Migliolo L, de Oliveira AS, Santos EA, Franco OL, de Sales MP (2010) Structural and mechanistic insights into a novel noncompetitive Kunitz trypsin inhibitor from Adenanthera pavonina $\mathrm{L}$. seeds with double activity toward serine- and cysteine-proteinases. J Mol Graph Model 29:148-156. https:// doi.org/10.1016/j.jmgm.2010.05.006

Notredame C, Higgins DG, Heringa J (2000) T-coffee: a novel method for fast and accurate multiple sequence alignment. J Mol Biol 302:205-217

Oard S, Karki B (2006) Mechanism of $\beta$-purothionin antimicrobial peptide inhibition by metal ions: molecular dynamics simulation study. Biophys Chem 121:30-43

Oliva MLV, Silva MCC, Sallai RC, Brito MV, Sampaio MU (2010) A novel subclassification for Kunitz proteinase inhibitors from leguminous seeds. Biochimie 92:1667-1673. https://doi. org/10.1016/j.biochi.2010.03.021

Oliveira CFR et al (2012) Purification and biochemical properties of a Kunitz-type trypsin inhibitor from Entada acaciifolia (Benth.) seeds. Process Biochem 47:929-935. https://doi.org/10.1016/j. procbio.2012.02.022

Onesti S, Brick P, Blow DM (1991) Crystal structure of a Kunitztype trypsin inhibitor from Erythrina caffra seeds. J Mol Biol 217:153-176. https://doi.org/10.1016/0022-2836(91)90618-g

Page KR, Chaisson R, Sande M (2008) CHAPTER 34-cryptococcosis and other fungal infections (histoplasmosis and coccidioidomycosis) in HIV-infected patients. In: Global HIV/AIDS medicine. W.B. Saunders, Edinburgh, pp 375-391

Ramalho SR et al (2018) A novel peptidase Kunitz inhibitor from Platypodium elegans seeds is active against Spodoptera frugiperda larvae. J Agric Food Chem 66:1349-1358

Ramos VdS et al (2012) Molecular cloning and insecticidal effect of Inga laurina trypsin inhibitor on Diatraea saccharalis and Heliothis virescens. Comp Biochem Physiol C Toxicol Pharmacol 156:148-158. https://doi.org/10.1016/j.cbpc.2012.07.007

Rawlings ND, Barret JA, Bateman A (2012) MEROPS: the database of proteolytic enzymes, their substrates and inhibitors. Nucleic Acids Res 40:D343-D350
Richardson M, Campos FAP, Xavier-Filho J, Macedo MLR, Maia GMC, Yarwood A (1986) The amino acid sequence and reactive (inhibitory) site of the major trypsin isoinhibitor (DE5) isolated from seeds of the Brazilian Carolina tree (Adenanthera pavonina L.). Biochim Biophys Acta (BBA) Protein Struct Mol Enzymol 872:134-140. https://doi.org/10.1016/0167-4838(86)90156-1

Sanglard D, Odds FC (2002) Resistance of Candida species to antifungal agents: molecular mechanisms and clinical consequences. Lancet Infect Dis 2:73-85

Sanglard D, Kuchler K, Ischer F, Pagani J, Monod M, Bille J (1995) Mechanisms of resistance to azole antifungal agents in Candida albicans isolates from AIDS patients involve specific multidrug transporters. Antimicrob Agents Chemother 39:2378-2386

Srinivasan A, Giri AP, Harsulkar AM, Gatehouse JA, Gupta VS (2005) A Kunitz trypsin inhibitor from chickpea (Cicer arietinum L.) that exerts anti-metabolic effect on podborer (Helicoverpa armigera) larvae. Plant Mol Biol 57:359-374

Sumikawa JT, Nakahata AM, Fritz H, Mentele R, Sampaio MU, Oliva MLV (2006) A Kunitz-type glycosylated elastase inhibitor with one disulfide bridge. Planta Med 72:393-397

Tang H et al (2014) An improved genome release (version Mt4. 0) for the model legume Medicago truncatula. BMC Genom 15:312

Taveira GB, Carvalho AO, Rodrigues R, Trindade FG, Da Cunha M, Gomes VM (2016) Thionin-like peptide from Capsicum annuиm fruits: mechanism of action and synergism with fluconazole against Candida species. BMC Microbiol 16:12

Terada S, Fujimura S, Kino S, Kimoto E (1994) Purification and characterization of three proteinase inhibitors from Canavalia lineata seeds. Biosci Biotechnol Biochem 58:371-375

Thery T, Arendt EK (2018) Antifungal activity of synthetic cowpea defensin Cp-thionin II and its application in dough. Food Microbiol 73:111-121

Thevissen K, Terras FR, Broekaert WF (1999a) Permeabilization of fungal membranes by plant defensins inhibits fungal growth. Appl Environ Microbiol 65:5451-5458

Thevissen K, Terras FRG, Broekaert WF (1999b) Permeabilization of fungal membranes by plant defensins inhibits fungal growth. Appl Environ Microbiol 65:5451-5458

Vriens K, Cammue B, Thevissen K (2014) Antifungal plant defensins: mechanisms of action and production. Molecules 19:12280-12303

Whaley SG, Berkow EL, Rybak JM, Nishimoto AT, Barker KS, Rogers PD (2016) Azole antifungal resistance in Candida albicans and emerging non-albicans Candida species. Front Microbiol 7:2173. https://doi.org/10.3389/fmicb.2016.02173

Wu Z et al (2003) Engineering disulfide bridges to dissect antimicrobial and chemotactic activities of human $\beta$-defensin 3. Proc Natl Acad Sci 100:8880-8885

Zaragoza O, Rodrigues ML, De Jesus M, Frases S, Dadachova E, Casadevall A (2009) The capsule of the fungal pathogen Cryptococcus neoformans. Adv Appl Microbiol 68:133-216. https://doi. org/10.1016/S0065-2164(09)01204-0

Zottich U et al (2013) An antifungal peptide from Coffea canephora seeds with sequence homology to glycine-rich proteins exerts membrane permeabilization and nuclear localization in fungi. Biochim Biophys Acta (BBA) Gen Subj 1830:3509-3516 